\title{
THE JUSTIFICATION OF PUNISHMENT
}

\author{
BARRY J. CAVANAUGH*
}

\begin{abstract}
The author deals extensively, in a philosophical vein, with the justification of punishment and the criminal law. Is there a right for society to protect itself? The argument herein tends to the apparently paradoxical conclusion that retribution may well be the most humane and most just basis for punishment.
\end{abstract}

\section{INTRODUCTION}

Our penal system has a threefold function. It seeks to punish the offender, tries to reform him, and aims to deter. ... .1

Any discourse concerned with the justification of punishment must, of necessity, pay respect to the justification of the criminal law which punishment seeks to enforce. As such, consideration must be given to some basic questions: Has society a right to pass judgment at all in matters of morals? Should there be a public morality, or are morals always a matter for private judgment? If society has a right to judge, does it have a right to use law to enforce what it may perceive as the commonly held standard of conduct?

A moral judgment by society is its distinction between good and evil. Yet, this does not necessarily imply any justification of a moral judgment based merely on the disapproving opinion of even an overwhelming majority. There is a valid case for such societal judgment only if society proper is affected. (Pragmatically, what is seen as injurious to the fabric of society must be prevailed against, or serious consequences result for the future of that society.) A society is nothing if not a community of concepts, including concepts of proper behaviour. These concepts are the morals of the society.

Sir Patrick Devlin, in The Enforcement of Morals, and elsewhere, likes to extend an argument similar to this by utilizing the political idiom for an example. Society, Devlin says, cannot tolerate rebellion, and cannot allow argument seeking to justify rebellion and concerned with the rightness of the cause. Society cannot survive if it permits untrammeled rebellion. So it must enforce against such rebellion. There is a parallel in the area of morality in the criminal law. If society has adopted a series of standards based on a moral law as its criminal law, there can be no dispute with the fact that, even though one feels unbound by the constraints of morality, society has no option but to insist that he abide by its criminal law. Assuming that the criminal law enacts fragments of a moral code which are essential to the society, there must be ordered and predictable community of behaviour, or society can no longer continue to exist as defined.

If society has no right to make judgments on moral issues and if it has no vested interest in the prevention or breach of moral standards, the law will need very special and unusual justification for dealing at all with morality. However, if society has a right to make a judgment on the basis of a recognized morality's indispensability to the fabric of society then

- LLB., articling with the firm of Berzins, Maher, Maclean, Walter \& Whiting, Edmonton, Alberta.

1. Pennell, Capital Punishment, 172. 
society may use the law to enforce that morality in the same way that it uses laws to protect anything else substantially necessary to its existence.

Nothing should be proscribed which is within the limits of tolerance. It is not sufficient to say that a vast majority dislike a given conduct; there must be a widespread, deep, reprobatory attitude-revulsion, perhaps. The existence of reprobation is an indication that the extremes of tolerance have been reached. Intolerance of some things is necessary to a society, for society by definition must have idea-community, and for every noble ideal there exists an ignoble opposite pole. Thus, if society holds at all strongly for one thing, it must be seized with the sense of intolerance for the opposite thing. It is simply in the nature of society. Intolerance of a given conduct generally will indicate that the conduct will be proscribed in the society's criminal law.

The criminal law, then, represents a society's limits of tolerance. One who merely avoids conflict with the criminal law is still far short of the "good citizen". He is, rather than striving to attain the noble ideal, barely avoiding the reprobation of the society in which he lives. The criminal law is not a statement of how people should behave, but a statement of the consequences to them should their conduct fall to an estate which society deems is intolerable and destructive.

The criminal law exists to protect society, not only by protecting the individual and his property from harm, but also by protecting the community of moral and political precepts which define the society. One may not share the morality of his society, but neither can one rationally deny that some such morality is necessary to the society's existence. Indeed, any opponent of a current morality will be prepared to institute moral codes of his own design should the occasion arise. As such, then, society cannot ignore the morality of the individual's behaviour. Society reacts with intolerance to those conducts which are detrimental to its fabric.

It follows logically that society, if endowed with the right to protect against certain types of repulsive conduct, has a right to impose some sort of consequence for transgression of its code. Indeed, this is the history of the criminal law.

From earliest times, criminal conduct has been recognized as an offence against social imperatives. There must, inevitably, be some response by society to intolerable conduct, whether it is called "retribution", "deterrence", "rehabilitation", or whatever. No matter what should be the effective consequence for the criminal in proscribed behaviour, there must logically be some consequence. Failing that, the society is condoning crime in its failure to react to breaches of acceptable conduct standards.

Punishment is the enforcement of responsibility. ${ }^{2} \mathrm{~A}$ member of society is obliged, by the prohibitive precepts of the criminal law, to refrain from violation of the minimal standards of the society. Enforcement of the responsibility not to violate the law normally involves the infliction of unpleasant consequences for the offender.

There are five elements to what is called punishment: ${ }^{3}$

(1) It involves pain or other consequences normally considered unpleasant;

2. Schafer, Theories in Criminology, 292

3. Hart, Punishment and Responsibility, 21. 
(2) It must be for an offence against legal rules;

(3) It must be of an actual or supposed offender for his offence;

(4) It must be intentionally administered by persons other than the offender;

(5) It must be imposed and administered by an authority constituted by a legal system against which the offence is committed.

\section{HISTORICAL CONSIDERATIONS}

Briefly, then, it is worthwhile to consider what the historical approach has been to this enforcement of responsibility, "punishment". The earliest known system of criminal law was included in the Code of Hammurabi, in Babylon, during the eighteenth century B.C. The thinking respecting punishment in this Code was essentially retributive. ${ }^{4}$ This, indeed, was the case with most early legal codes, such as Mosaic or Roman law. The emphasis was on a "paying back" in one form or another.

In more primitive societies the concept of retribution was, of course, the primary thrust, though the matter of securing retribution was in the hands of the offended individual or his family, rather than in "society's". ${ }^{5}$ The Germanic tribes, though undoubtedly preliterate and "primitive" prior to the conquests of Rome, recognized a number of crimes against the tribe, as well as the usual other crimes against the individual. ${ }^{6}$ The tribe extracted retribution for these crimes, usually in the form of execution, mutilation, or ransom.

In Britain, prior to the twelfth century, the realm was broken into a shire system, and sheriffs assisted in obtaining compensation from an offender to be paid his victim. ${ }^{7}$ Hence, the system was partially one of private crimes, and of course even then there were distinct crimes against the Crown.

Then, during the twelfth century, a trend began where the Crown started to administer all levels of justice, and a systematized method of punishment emerged. ${ }^{8}$ This was essentially parallel to developments in Europe. Forms of punishment from the medieval period forward represented a retaliatory theme in their severity and supposed equality of force and seemed also to seek a deterrent force, both as against the offender himself, to prevent his repetition of the offence, and as warning to potential offenders of the dire results of criminal behaviour. Various types of corporal and capital punishment and exile are evidence of this thinking.

In the sixteenth century, Britain established the first forerunners of imprisonment as a form of punishment in itself, with "Bridewell" and similar houses.9 These were essentially houses of detention and work for vagrants and the like. However, prisons and penitentiaries in the modern sense did not develop widely until the nineteenth century in America.10

Capital punishment, of course, was a means of punishment used widely in the past in all societies. Capital punishment has clear retributive

4. Gibbons, Society, Crime and Criminal Careers, 444.

5. Hoebel, Law of Primitive Man, 296.

6. Gibbons, Society, Crime and Criminal Careers, 444.

7. Id. at 444 .

8. Id. at 444 .

9. Id. at 445 .

10. Id. at 445 . 
value and is perhaps possessed of some deterrent justification, at least with respect to the individual offender.

Penitentiaries, in the modern sense, are an American invention from the early nineteenth century, and imprisonment as punishment in itself stems from here. The motive undertones attached to such imprisonment have historically been, and still seem to be, those of expiation, retaliation, and prevention or deterrence.

The foregoing historical discussion, brief though it is, serves to demonstrate the fact that certain themes with respect to punishment have consistently been with man as long as his time on earth, and probably are still with us-most notably, retaliation or retribution and deterrence.

\section{THEMES OF MOTIVES FOR PUNISHMENT}

Tappan ${ }^{11}$ has observed that punishment is designed to achieve retribution or social retaliation against the criminal, incapacitation or prevention, and deterrence both individual and general-the individual through either fear of similar consequences for repetition or through reform of his deviant thinking and society by example, as warning of what will happen to other misbehavers. Tappan contends that retribution is still a major component in society's aims in the punishment of criminals, ${ }^{12}$ and he is not alone in thinking so.

It is reasonable to suggest that a criminal law system is, or ought to be, concerned with three essential and major themes to justify the punishment of offenders. First, of course, we recognize from the moral or societal argument that society has a right to react in some manner. The reaction of any society to crimes as aginst its minimal code must, of necessity, from the earlier positions, be based in what is essentially revulsion for the behaviour.

In this view, there are three central trends, or schools of thought, respecting the justification and aims of punishment. It is appropriate to consider each of these briefly, prior to examining the legitimacy of each and whether there is some sort of connection between them.

\section{A. The Expiatory View}

One view is best described as "expiatory". This view holds, essentially, that punishment is a purging of guilt for the offender, or a "payment of his debt to society". ${ }^{13}$ This school of thought tends to ease the burden of guilt, and is responsible for the notion that, once punishment is inflicted, an offender's past crimes should not be held against him. ${ }^{14}$ This notion is quite prominent in religious doctrine, notably to the western world in Christianity. ${ }^{15}$ Expiation is symbolized in the Cross, as a supreme act of expiation by Jesus Christ, "paying the debt" for all the sins of man. Surely in any society which bases its moral code, and this criminal law, on the Judaeo-Christian moral code, this notion is interwoven with any other aims of punishment. The view is rather commendable, in that it secures for the offender some degree of dignity-the dignity plainly due a member of society and a subject of rights.

11. Tappan, Crime, Justice and Correction, 241-246.

12. Id. at 242

13. Jones, Crime and the Penal System, 133.

14. Id. at 134 .

15. Id. at 135 . 


\section{B. The Retributive View}

Another view holds that there is and should be a retributive value in punishment. It is tied to expiation in that it seeks to restore the moral balance which has been upset by the offence. The difference between the expiatory and retributive views is that the retributive notion is quite unconcerned with the "moral purgation" of the criminal. Expiation is perhaps for the benefit of the offender, while retribution is that which is deserved.16 Retribution is the just consequence of his anti-moral behaviour. It is punishment in its purest form. ${ }^{17}$ Thus, retribution is at the centre of any consideration of the aims or the justification of punishment.

Retribution is probably the sole view most commonly adhered to by the general public or the "reasonable man". It is, moreover, a view which is apparently central to our criminal law. It is demonstrably so in the Criminal Code, ${ }^{18}$ where attempts have clearly been made to vary punishments according to evil represented-punishments vary in severity, kind, and application, to "let the punishment fit the crime." As one peruses the Criminal Code, examples abound of lesser penalties for lesser crimes, and more severe penalties for those conducts viewed generally as more repugnant.

\section{Sir Arthur L. Goodhart suggests that: ${ }^{19}$}

Retribution in punishment is an expression of the community's disapproval of crime, and if this retribution is not given recognition, then the disapproval may also disappear.

A community which is too ready to forgive the wrongdoer may end by condoning crime. To say that support for this view of punishment is widespread among leaders in the judiciary and in government is almost an understatement. ${ }^{20}$

\section{The Deterrent View}

It is often postulated that there is some substantial difference between the notions of retribution and deterrence. Deterrence, plainly, is another widely accepted aim or justification for punishment.

The Shorter Oxford English Dictionary says that to deter is to "discourage or restrain by fear or by consideration of danger or trouble." Deterrence, then, is a way of maintaining control of conduct through fear of consequence. The notion that punishment deters criminal conduct is based on a hedonistic assumption-that man regulates his behaviour by calculation of pleasure and pain.21 The essence of this view is, put briefly, that there are two types of deterrence-individual and general, and that they operate on a calculating and rational mankind. The theory holds that individual deterrence is achieved by intimidation and punishment of the offender, frightening him as to the consequences of future repetition of criminal conduct; or, it may reform the thinking of the criminal and may be a time of penance. General deterrence is achieved by the example of punishment for offenders-a warning to all members of society that certain conduct is not tolerated and bears serious consequences.22 Again, the underlying assumption is that man is a rational and calculating being who will seek pleasure and avoid pain.

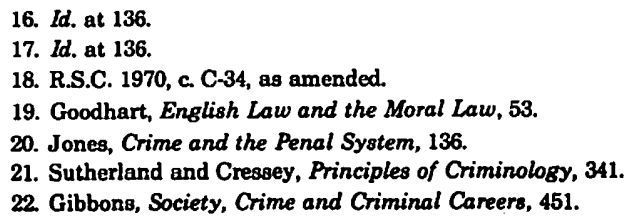


M. V. Julian offers some thoughts on deterrence in punishment. ${ }^{23} \mathrm{He}$ suggests that, even from the point of view of a determinist, deterrence is a legitimate aim of punishment, because:24

Deterrence is, indeed, possible, even though for a particular person and a given set of external and internal elements, a particular crime is inevitable. The threatened imposition of a penal sanction simply works an alteration on the totality of environmental forces.

Tappan views deterrence as having, in addition to its negative value, the positive value of operating to bolster the society's moral code, bringing about deterrence through formation of conformist habits, and leading to internalization of the belief that certain types of conduct are reprehensible. ${ }^{25}$

\section{CONSIDERING EFFICACY}

What, now, can be said respecting the real efficacy of punishment with respect to each of the three views discussed? A consideration of efficacy is undoubtedly justified, since if punishment for these reasons has no effect, it cannot be of any value to society, and as aims and justifications, these views are invalid.

The first suggestion which one might pose is that, from history, we know that these are our oldest continuing aims in punishment. But to say that their existence alone now proves that these aims are efficacious is an argument post hoc ergo propter hoc, and thus fallacious. So it appears as though real efficacy must be examined from the point of view of theoretics, with aid of what statistics are of value and available; yet, this question of theoretics is precisely what leads to various schools of thought respecting the aims of punishment.

If we consider that, as posited earlier, the primary aim of punishment is the expression of society's revulsion for the conduct committed, the question of efficacy takes on a different colour. As has been pointed out, there can only be justification for punishment in condemnation of the conduct. Clearly, society does not condone the behaviour, and does not want it acted out by anyone. Thus, the moral-legal position argued earlier leads to the concept that society must necessarily react in retaliation when it reacts to crime, in order to restore the balance necessary to the continuation of that society as defined. If it does not react because the conduct is morally unacceptable, then it has no business in reacting at all. It must also, concomitant with the retributional aspect, seek to prevent repetition of the offence, either by the present perpetrator or by others. Thus, society is concerned with deterrence, which also comprises reform and rehabilitation of the offender. Our notion of justice, or fairness, moreover demands that the moral imbalance be redressed-but also demands that once the "debt is paid", the offender be punished no more, for to punish beyond sufficiency for the crime is to persecute.

\section{A. Retribution}

We can state definitively that retribution as an aim is efficacious, in that we seek retaliation only. The true question of efficacy respecting retribution is concerned with whether our retaliation is equal in kind and

23. Julian, Determinist's Perspective of Criminal Responsibility, 381 .

24. Id. at 381.

25. Gibbons, Society, Crime and Criminal Careers, 451. 
severity to the intolerance in which we regard the sanctioned conduct called the crime. In this regard, there are problems with the retributive view. Perhaps, in meting out a fair punishment, we must face the problem of assessing culpability or extenuating circumstances. This must inevitably lead to varying degrees of responsibility, variation in the penalties imposed, and the possibility that one offender may suffer more greatly than another from the identical punishment for the identical crime. The criticism is that we face-in so doingvarying what is "just" and negating the value of retribution. However, true retribution must be more concerned with meting out fair punishment to achieve a given end result for a crime than simply with reacting or with strict literal equality of severity. Therefore, true retribution, of the kind the Criminal Code attempts to practice, is as close as possible to our traditional concept of "justice".

Of course, punishment is often criticized from the point of view that it may be evil to inflict suffering even in return for a heinous crime-for if morality is our dominant concern, Christian morality teaches foregiveness as a cardinal virtue, and shuns the infliction of suffering. In answer to this criticism, it must first be said that punishment need not inflict suffering in a literal sense-but must always exist as a reaction to crime. The form it takes is according to what is just, and so in fact may not be contrary to Christian principle. A further answer to this criticism is that its proponents have oversimplified the case of Christianity-for justice and punishment, suffering and purgation are within the confines of sound Christian doctrine. It is simply far too superficial a criticism.

It is too easy to dismiss retribution as being barbaric or vengeful. Man's nature contains a sense of just vengeance-the need to return blow for blow, and too many moral and religious codes, the cornerstones of civilization, favour retribution for it to be so lightly dismissed.26 Certainly, suffering inflicted by society on the criminal is the societal counterpart of individual revenge.27 Since the Hammurabic Code, and well prior to that on an informal level, it has been accepted that a criminal deserves to suffer for his crime.

There is, no doubt, some justification for a motive of retribution as an element in punishment. C. S. Lewis has defended the concept of retribution against the criticism that it is mere barbarous, immoral revenge and that deterrence and reform are the sole legitimate motives for punishment. Lewis suggests that reform tends to degenerate to a notion of "curing" or "healing", and punishment becomes "therapy". ${ }^{28}$ But, Lewis points out, the "cure" is just as compulsory and inflicted a result as it was when it was called punishment. Perhaps it is even retributive, though modified only in form.

According to Lewis, the "humanitarian" theory excises all notion of "desert"; but desert is the sole connection between punishment and justice. He suggests that it is only "as deserved or undeserved that a sentence can be just or unjust."29 No "deterrence" or "cure", it appears, can be considered with respect to its justness, if the motive of retribution is removed. Lewis goes so far as to suggest that: ${ }^{30}$

26. Cohen, Moral Aspects of Punishment, 27.

27. Sutherland and Cressey, Principles of Criminology, 341.

28. Lewis, Humanitarian Theory of Punishment, 43.

29. Id. at 44.

30. Id. at 44 . 
When we cease to consider what the criminal deserves and consider only what will cure him or deter [him or] others, we have tacitly removed him from the sphere of justice altogether; instead of a person, a subject of rights, we now have a mere object, a patient, a 'case'.

The implication is that "cure" or "deterrence" alone as motives for punishment are extreme, making the criminal an example, no matter how unjustly, or a patient, a subject of "science", no matter how unjustly. Without retribution as an element, these motives for punishment are devoid of the moral concept of justice.

Lewis' point of view is, then, well taken. It seems that retribution is well entrenched in our common understanding and in our notions of justice. In fact, even "justice" herself is usually depicted holding a sword and a scale.

\section{B. Deterrence}

Deterrence as a motive for punishment is indeed legitimate in the scheme of things posed earlier as a moral-legal background to the justification of punishment. Deterrence flows logically, as an aim, from the notion that society must stigmatize certain types of conduct in order to survive. Thus, one need not be overconcerned with a philosophical efficacy for the aim of deterrence. However, where retribution is obviously effective in a practical sense, is deterrence effective practically? It is efficacious and legitimate in a theoretical sense, flowing as it does so logically from our earlier considerations. No study undertaken by statistical methods can, it seems, ever fully answer whether a deterrent aim is practically effective. Possibly, man is, to some degree at least, sufficiently hedonistic to bear out the theory; however, empirical evidence is lacking indeed, due to the very nature of deterrence. Perhaps the only evidence which would be available would be so if punishment failed in a deterrent aim, in which case the proscribed behaviour would be more or less widespread. Some may argue that the sizable rates of recidivism militate against a conclusion that punishment has a deterrent effect. Yet, a complete failure of prevention cannot be inferred from the serious crimes committed by a small percentage of the population any more than its success is indicated by the obedience of most. ${ }^{31}$ In essence, we cannot know certainly whether deterrence is an effective result of punishmentthough we can say in the theoretical sense that it may well be.

\section{Expiation}

Expiation, of course, is efficacious in the sense that, if we adopt it, we do justice in the sense that we forgive an offender who has "paid his debt" by punishment. It has considerable merit, in that he may feel free from moral stigma, once his punishment is completed.

\section{OTHER THEORIES}

Other theories presuming justification as the aims of punishment have been put forward from time to time: reform, restoring the solidarity of the group and the healing of aberrant attitudes are some examples. Eventually and inevitably these aims reduce logically to subsumption under the three main aims posited in this examination. Reform and healing of 
attitudes are, in their essence, forms of individual deterrence. They are logically subsumed but, if used alone as aims for punishment, remove the offender from the realm of rights and justice, as Lewis has rightly pointed out. Thus, any just application of such notions implies that they are no more than varied methods of carrying out the three main aims of punishment. As for the notion of "restoring the solidarity of the group", this is simply sociological jargon for redressing the moral balance, in the sense discussed earlier, in connection with retribution.

\section{ACHIEVEMENT OF THE AIMS}

Since expiation of guilt, retribution for wrong done, and deterrence of both the criminal and others from future repetition are the aims of punishment, it is appropriate to consider whether our criminal legal system, in its practical application, is near achieving these aims satisfactorily. This is the true question for those of us who are concerned with justice and punishment-not whether these are the proper motives. Our criminal law must strive to be effective, unabashedly, in meting out just retribution, in establishing reasonable and efficacious deterrence, and in allowing the purgation of guilt. Our aims must be to achieve these motives in a more perfect manner rather than abandoning them for, in abandoning them, we abandon justice.

With respect to retribution, we must seek to find a fair and just response to a given unacceptable conduct, sufficiently indicative of society's current reprehension of the offence while, at the same time, equally concerned with justice, considering the culpability of the individual rather than merely the nature of the crime. With respect to deterrence, we must cautiously consider that in our practical experience, some consequences are distasteful to people, and impose those consequences to both deter commission of offences and express society's repugnance of them. With respect to expiation, perhaps we must strive to achieve sufficient justice and fairness in our law and in our attitudes to be able to forgive an offender for his past crimes-crimes for which the balance has been redressed. We must, as the Bible says, "love the sinner, but hate the sin."

If crime is inevitable, so also is society's resistance to it. ${ }^{32}$ We may agonize over the difficulty of conscience in inflicting punishment, but it is a matter of necessity for the survival of society as defined, and our aim must be to embrace our moral code more strongly, and in so doing to mete out punishment as justly as is humanly possible. Society cannot allow the necessity of reaction against crime to be so distasteful as to negate any effective reaction-for in so doing the values which are integral to the fabric of the society must be destroyed or submerged. 